\title{
Dispersion curves for minerals, immersion liquids and glasses
}

\author{
HARRY MICHEELSEN
}

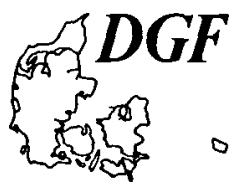

Micheelsen, H.: Dispersion curves for minerals, immersion liquids and glasses. Bull. geol. Soc. Denmark, vol. 27, special issue, pp. 47-53. Copenhagen, July 30th, 1978. https://doi.org/10.37570/bgsd-1978-SI-06

A new dispersion formula gives accuracy to the 5 th decimal place for the refractive index dispersion curves. Empirical constants are listed for minerals, immersion liquids and optical glasses. Auxilliary formulas and a flow programme for double variation refractive index determination are given.

Harry Micheelsen, Institut for Mineralogi, Østervoldgade 5-7, DK-1350 København K, Denmark. January 16 th, 1978

During an interferometric study of minerals in thin section difficulties in determinating high orders of interference turned out to be due to lack of knowledge of the dispersion curves of the minerals. The dispersion formulas of Hartmann (1898) and Cauchy (1830) give errors of more than $-\overline{10^{-3}}$ and will often make interferometric R.I. determinations impossible. Detailed calculations showed that each of the above mentioned dispersion formulas had advantages, and an attempt was therefore made to combine both formulas thus:

$$
\mathrm{n}(\lambda)=\mathrm{N}+\frac{\mathrm{M}}{\left(\lambda-\lambda_{0}\right)^{\mathrm{p}}}+\frac{\mathrm{L}}{\left(\lambda-\lambda_{0}\right)^{2 \mathrm{p}}} \text {. }
$$

where $n(\lambda)$ is the refractive index at wavelength $\lambda$. $\mathrm{N}, \mathrm{M}, \mathrm{L}, \mathrm{p}$ and $\lambda_{0}$ are constants. If $\lambda_{0}$ and $\mathrm{p}$ are known this formula is suited for an automatic least squares refinement (computer programm in RPN for HP 9815 A available from the author) for determining $\mathrm{N}, \mathrm{M}$, and $\mathrm{L}$, using

$$
\mathrm{n}(\lambda)=\mathrm{N}+\mathrm{MX}+\mathrm{L} \mathrm{X}^{2} \text {, }
$$

where $X=\left(\lambda-\lambda_{0}\right)^{-p}$.

$\lambda_{0}$ and $\mathrm{p}$ were determined by a least squares refinement from the refractive index data for quartz determined by Sosman (1927) because of the extreme accuracy $\left( \pm 3 \times 10^{-6}\right)$ of these measurements. The optimum values of $\lambda_{0}$ and $p$ are $\lambda_{0}=$ $311.33 \mathrm{~nm}$ and $\mathrm{p}=\mathbf{0 . 5 3 5}$ giving a standard deviation between calculated and measured refractive indices of $4 \times 10^{-6}$. A contour map giving standard deviation as a function of $\lambda_{0}$ and $p$, however, showed that around $\lambda_{0} \sim 311 \mathrm{~nm}$ and $\mathrm{p} \sim 0.54$ small changes in $\lambda_{0}$ and $p$ would rapidly impair the calculated dispersion curve. Another optimum around $\lambda_{0}=180 \mathrm{~nm}$ and $\mathrm{p}=0.6$ is much broader, but here the standard deviation is no better than $8 \times 10^{-6}$.

\section{Minerals}

To increase the field of application of the dispersion formula 32 sets of dispersion data significant to 5 places of decimal representing 9 different minerals (Mülheims 1888) were used in a least squares refinement for $\lambda_{0}$ and $p$. This gave an optimum around $\lambda_{0}=167 \mathrm{~nm}$ and $\mathrm{p}=0.5$ with a standard deviation of $29 \times 10^{-6}$ for the 32 mineral dispersion curves. For the quartz data of Sosman (1927) the standard deviation here becomes $11 \times 11^{-6}$. An average value covering quartz as well as the other minerals is $\lambda_{0}=180 \mathrm{~nm}$ and $\mathrm{p}=\mathbf{0 . 5}$. Here the standard deviation is for quartz $8 \times 10^{-6}$ and for the 32 mineral curves $29 \times 10^{-6}$. The dispersion formula for minerals thus becomes:

$$
\mathrm{n}=\mathrm{N}+\frac{\mathrm{M}}{\sqrt{\lambda-180}}+\frac{\mathrm{L}}{(\lambda-180)},
$$

or using the average $D$-line: $\lambda=589.29 \mathrm{~nm}$ :

$$
\begin{aligned}
& \mathrm{n}=\mathrm{n}(\mathrm{D})+\mathrm{M} \times\left(\frac{1}{\sqrt{\lambda-180}}-0.0494287\right)+ \\
& \mathrm{L} \times\left(\frac{1}{\hbar-180}-0.0024432\right),
\end{aligned}
$$

Dispersion coefficients for some of the minerals used are given in table 1. 
Table 1. Dispersion coefficients for the minerals used for establishing the dispersion formula.

\begin{tabular}{|c|c|c|c|c|c|}
\hline $\begin{array}{l}\lambda_{0}=180 \mathrm{~nm}, \mathrm{p}=0.5 \\
\text { wavelength in } \mathrm{nm}\end{array}$ & & $\mathrm{n}(\mathrm{D})$ & $\begin{array}{l}n(F)-n(C) \\
\quad \times 10^{-3}\end{array}$ & $\mathbf{M}$ & $\mathbf{L}$ \\
\hline Anhydrite, Stassfurt & $\begin{array}{l}\alpha \\
\beta \\
\gamma\end{array}$ & $\begin{array}{l}1.56937 \\
1.57523 \\
1.61306\end{array}$ & $\begin{array}{l}7.58 \\
7.92 \\
8.23\end{array}$ & $\begin{array}{l}0.0183 \\
0.0797 \\
0.4128\end{array}$ & $\begin{array}{l}6.315 \\
6.009 \\
3.047\end{array}$ \\
\hline Aragonite, Bilin & $\begin{array}{l}\alpha \\
\beta \\
\gamma\end{array}$ & $\begin{array}{l}1.52991 \\
1.68097 \\
1.68540\end{array}$ & $\begin{array}{r}6.56 \\
12.75 \\
13.13\end{array}$ & $\begin{array}{r}-0.1402 \\
0.0824 \\
0.0667\end{array}$ & $\begin{array}{r}6.983 \\
10.125 \\
10.602\end{array}$ \\
\hline Baryte, Cornwall & $\begin{array}{l}\alpha \\
\beta \\
\gamma\end{array}$ & $\begin{array}{l}1.63612 \\
1.63729 \\
1.64816\end{array}$ & $\begin{array}{l}9.03 \\
9.18 \\
9.47\end{array}$ & $\begin{array}{l}0.1017 \\
0.0825 \\
0.1175\end{array}$ & $\begin{array}{l}6.750 \\
7.068 \\
6.973\end{array}$ \\
\hline Calcite & $\begin{array}{c}\omega \\
\varepsilon\end{array}$ & $\begin{array}{l}1.65846 \\
1.48630\end{array}$ & $\begin{array}{r}13.52 \\
6.06\end{array}$ & $\begin{array}{l}-0.1143 \\
-0.3711\end{array}$ & $\begin{array}{r}12.697 \\
8.798\end{array}$ \\
\hline Colemanite, California & $\begin{array}{l}\alpha \\
\beta \\
\gamma\end{array}$ & $\begin{array}{l}1.58626 \\
1.59200 \\
1.61404\end{array}$ & $\begin{array}{l}8.70 \\
8.89 \\
9.49\end{array}$ & $\begin{array}{l}1.0153 \\
0.7510 \\
1.0088\end{array}$ & $\begin{array}{r}-2.401 \\
0.328 \\
-1.662\end{array}$ \\
\hline Fluorite & & 1.43384 & 4.45 & 0.1127 & 2.723 \\
\hline Gypsum, Sicily & $\begin{array}{l}\alpha \\
\beta \\
\gamma\end{array}$ & $\begin{array}{l}1.52078 \\
1.52275 \\
1.52983\end{array}$ & $\begin{array}{l}7.77 \\
7.84 \\
8.10\end{array}$ & $\begin{array}{l}0.3917 \\
0.4906 \\
0.5765\end{array}$ & $\begin{array}{l}2.854 \\
1.953 \\
1.341\end{array}$ \\
\hline Halite, Friederichshall & & 1.54385 & 12.66 & -0.1152 & 11.964 \\
\hline Quartz (Sosman, 1927) & $\begin{array}{l}\omega \\
\varepsilon\end{array}$ & $\begin{array}{l}1.544234 \\
1.553343\end{array}$ & $\begin{array}{l}7.801 \\
8.067\end{array}$ & $\begin{array}{l}0.23134 \\
0.23773\end{array}$ & $\begin{array}{l}4.4386 \\
4.6044\end{array}$ \\
\hline Quartz & $\begin{array}{c}\omega \\
\varepsilon\end{array}$ & $\begin{array}{l}1.54420 \\
1.55330\end{array}$ & $\begin{array}{l}7.81 \\
8.09\end{array}$ & $\begin{array}{l}0.2958 \\
0.1882\end{array}$ & $\begin{array}{l}3.822 \\
5.106\end{array}$ \\
\hline Sanidine, Wehr & $\begin{aligned} & \alpha \\
= & \gamma\end{aligned}$ & $\begin{array}{l}1.51986 \\
1.52442\end{array}$ & $\begin{array}{l}8.08 \\
8.14\end{array}$ & $\begin{array}{r}-0.0332 \\
0.2468\end{array}$ & $\begin{array}{l}7.247 \\
4.581\end{array}$ \\
\hline $\begin{array}{l}\text { Sanidine } 0^{\circ} \mathrm{C} \text {, Duckweiler } \\
\quad \text { (Offret, 1890) }\end{array}$ & $\begin{array}{l}\alpha \\
\beta \\
\gamma\end{array}$ & $\begin{array}{l}1.52058 \\
1.52513 \\
1.52521\end{array}$ & $\begin{array}{l}8.01 \\
8.10 \\
8.21\end{array}$ & $\begin{array}{l}-0.3168 \\
-0.3339 \\
-0.3155\end{array}$ & $\begin{array}{r}9.944 \\
10.187 \\
10.094\end{array}$ \\
\hline Topaz, Brazilia & $\begin{array}{l}\alpha \\
\beta \\
\gamma\end{array}$ & $\begin{array}{l}1.62938 \\
1.63081 \\
1.63752\end{array}$ & $\begin{array}{l}8.17 \\
8.04 \\
8.12\end{array}$ & $\begin{array}{l}0.3938 \\
0.3636 \\
0.3816\end{array}$ & $\begin{array}{l}3.181 \\
3.362 \\
3.248\end{array}$ \\
\hline Topaz, Nertschinsk & $\begin{array}{l}\alpha \\
\beta \\
\gamma\end{array}$ & $\begin{array}{l}1.61326 \\
1.61597 \\
1.62254\end{array}$ & $\begin{array}{l}7.80 \\
7.71 \\
7.76\end{array}$ & $\begin{array}{l}0.2886 \\
0.3234 \\
0.3769\end{array}$ & $\begin{array}{l}3.878 \\
3.465 \\
2.991\end{array}$ \\
\hline Topaz, Schneckenstein & $\begin{array}{l}\alpha \\
\beta \\
\gamma\end{array}$ & $\begin{array}{l}1.61551 \\
1.61808 \\
1.62501\end{array}$ & $\begin{array}{l}7.83 \\
7.68 \\
7.72\end{array}$ & $\begin{array}{l}0.4567 \\
0.5140 \\
0.6143\end{array}$ & $\begin{array}{l}2.274 \\
1.592 \\
0.649\end{array}$ \\
\hline
\end{tabular}

The figures in this table are calculated from data given by Mülheims (1888) unless otherwise indicated. The line $b_{27}$ is omitted.

The dispersion $n(F)-n(C)$ can be calculated from $M$ and $L$ as:

$$
n(F)-n(C)=0.01133223 \times M+0.00116694 \times L
$$

Otherwise there is no simple relation between $M$, $L$ and $n(F)-n(C)$. Plots of $L$ versus $n(F)-n(C)$ and $M$ versus $n(F)-n(C)$ show considerable scatter, but also general trends corresponding to:

$$
\begin{aligned}
& M \simeq-44 \times(n(F)-n(C))+0.58 \\
& L \simeq 1386 \times(n(F)-n(C))-7.9
\end{aligned}
$$

which may be used as rough approximations in form:

$$
\begin{array}{r}
n(\lambda)-n(D) \simeq \\
(n(F)-n(C)) \times\left(\frac{-44}{\sqrt{\lambda-180}}+\frac{1386}{(\lambda-180)}-1.2115\right) \\
+\left(\frac{0.58}{\sqrt{\lambda-180}}-\frac{7.9}{(\lambda-180)}-0.0094\right)
\end{array}
$$

In interferometric determinations of refractive indices the last bracket will disappear, because our observations concern a difference between two minerals at the same wavelength. 


\section{Immersion liquids}

The dispersion formula - eq. 4 - found for minerals is not suited for liquids. For the immersion liquid series Nujol (Ph.Dan.) 1.4806 - $\alpha$-monobromonaphtalene (Merck) 1.6565 and $\alpha$-monobromonaphtalene (Merck) 1.6565 - diiodomethane (Merck) 1.7377 mag. scient. John RoseHansen and the author in 1959 determined the dispersion curves at ca. $24^{\circ} \mathrm{C}$ and at ca. $48^{\circ} \mathrm{C}$ with an accuracy of better than $\pm 4 \times 10^{-5}$. The curves have been used for double variation measurements since and the figures were therefore available for numercial treatment. Least squares refinements for $\lambda_{0}$ and $\mathrm{p}$ showed that $\mathrm{p}$ is nearly constant at $\sim 1.2$ for the liquids, but that the optimal $\lambda_{0}$ values range from $70 \mathrm{~nm}$ to $210 \mathrm{~nm}$. A least squares refinement applied to all the liquids gave the average values $\lambda_{0}=190 \mathrm{~nm}$ and $p=1.23$, which give a standard deviation of $17 \times 10^{-6}$ for all these liquids. Dispersion coefficients for the immersion liquids are given in table 2. In the two mixture series $M$ and $L$ vary smoothly with $n(D)$. Interpolation functions were therefore determined by least squares parabola fits giving for the low index series

1.481-1.657, wavelength and temperature in brackets:

$$
\begin{gathered}
\mathrm{M}(24)=427.029710+365.796377 \times \mathrm{n}(\mathrm{D}, 24)- \\
40.706504 \times \mathrm{n}^{2}(\mathrm{D}, 24)
\end{gathered}
$$

and

$$
\begin{gathered}
L(24)=-36117.68-25911.98 \times n(D, 24)+ \\
32829.56 \times n^{2}(D, 24)
\end{gathered}
$$

for the high index series 1.657-1.738:

$$
\begin{aligned}
& \mathrm{M}(24)=153.071121-218.229664 \times \mathrm{n}(\mathrm{D}, 24)+ \\
& 100.425447 \times \mathrm{n}^{2}(\mathrm{D}, 24) \\
& \text { and } \\
& \mathrm{L}(24)=339422.0-402582.8 \times \mathrm{n}(\mathrm{D}, 24)+ \\
& \quad 123300.1 \times \mathrm{n}^{2}(\mathrm{D}, 24)
\end{aligned}
$$

and

The use of these interpolation formulas however increases the standard deviation between calculated and measured refractive indices to $35 \times 10^{-6}$ in the low series and to $55 \times 10^{-6}$ in the high series. Nevertheless, the accuracy is sufficient for nearly all optical work in powder specimens.

From the goniometric measurements at ca. $24^{\circ} \mathrm{C}$ and at ca. $48^{\circ} \mathrm{C}$ the temperature coefficients for $n(D)$ are calculated, table 2 . In the low series (1.481-1.657) we can interpolate by

$$
\frac{\Delta \mathrm{n}(\mathrm{D})}{\Delta \mathrm{t}}=(-2206.5+2946.7 \times \mathrm{n}(\mathrm{D}, 24)-
$$$$
\left.1157.5 \times \mathrm{n}^{2}(\mathrm{D}, 24)\right) \times 10^{-6} \text { degree }^{-1}
$$

(eq. 11)

In the high series (1.657-1.737) we can interpolate

$$
\text { by } \frac{\Delta n(D)}{\Delta t}=(54767.9-62438.9 \times n(D, 24)+
$$

$$
\left.17551.9 \times \mathrm{n}^{2}(\mathrm{D}, 24)\right) \times 10^{-6} \text { degree }^{-1} \text { (eq. 12) }
$$

According to Lorenz (1863-64) and Lorentz (1880) the specific refraction $r=\frac{1}{d} \times \frac{n^{2}-1}{n^{2}+2}$ where $\mathrm{d}$ is the density, is independent of temperature, but varies with the wavelength.

In order to describe the temperature dependence of the dispersion we use the expression

Table 2. Dispersion coefficients for immersion liquids at $24.0^{\circ} \mathrm{C}$.

\begin{tabular}{|l|c|c|c|c|c|}
\hline $\begin{array}{l}\lambda_{0}=190 \mathrm{~nm}, \mathrm{p}=1.23 \\
\text { wavelength in } \mathrm{nm}\end{array}$ & $\mathrm{n}(\mathrm{D})$ & $\begin{array}{c}\mathrm{n}(\mathrm{F})-\mathrm{n}(\mathrm{C}) \\
\times 10^{-3}\end{array}$ & $\mathrm{M}$ & $\mathrm{L}$ & $\begin{array}{c}\frac{\Delta \mathrm{n}(\mathrm{D})}{\Delta \mathrm{t}} \\
\mathrm{x} 10^{-4} \\
\mathrm{degree}^{-1}\end{array}$ \\
\hline Nujol, pH. Dan. & 1.48060 & 8.50 & 25.07 & -2286 & -3.82 \\
mixture & 1.51940 & 13.70 & 35.28 & -134 & -4.02 \\
$"$ & 1.56002 & 19.27 & 44.70 & 3269 & -4.20 \\
$"$ & 1.59214 & 23.65 & 51.52 & 6332 & -4.53 \\
$\#$ & 1.62283 & 27.85 & 59.62 & 8182 & -4.78 \\
a-monobromonaphtalene, Merck & 1.65654 & 32.40 & 67.29 & 10960 & -4.98 \\
mixture & 1.67390 & 33.11 & 69.46 & 10722 & -5.71 \\
$"$ & 1.69517 & 34.41 & 71.31 & 11758 & -6.41 \\
$"$ & 1.71400 & 35.50 & 74.74 & 11303 & -6.84 \\
Diiodomethane, Merck & 1.73770 & 36.94 & 77.09 & 12240 & -7.34 \\
\hline
\end{tabular}

The figure in this table are based on the measurements made by John Rose-Hansen and the author. 
Table 3. Flow programme for refractive index determination by variation of wavelength and temperature - the double variation method - using optical glass as internal standard. Operational blocks marked with " $P$ " involves "personal" operations, those marked with " $C$ " are calculations made by the computer.
Subscript " $g$ " indicates glass. Subscript "l" indicates liquid. Subscript " $\mathrm{m}$ " indicates mineral. Flow programmes for other types of refractive index measurements and corresponding computer programmes in RPN for HP 9815A are available from the author.

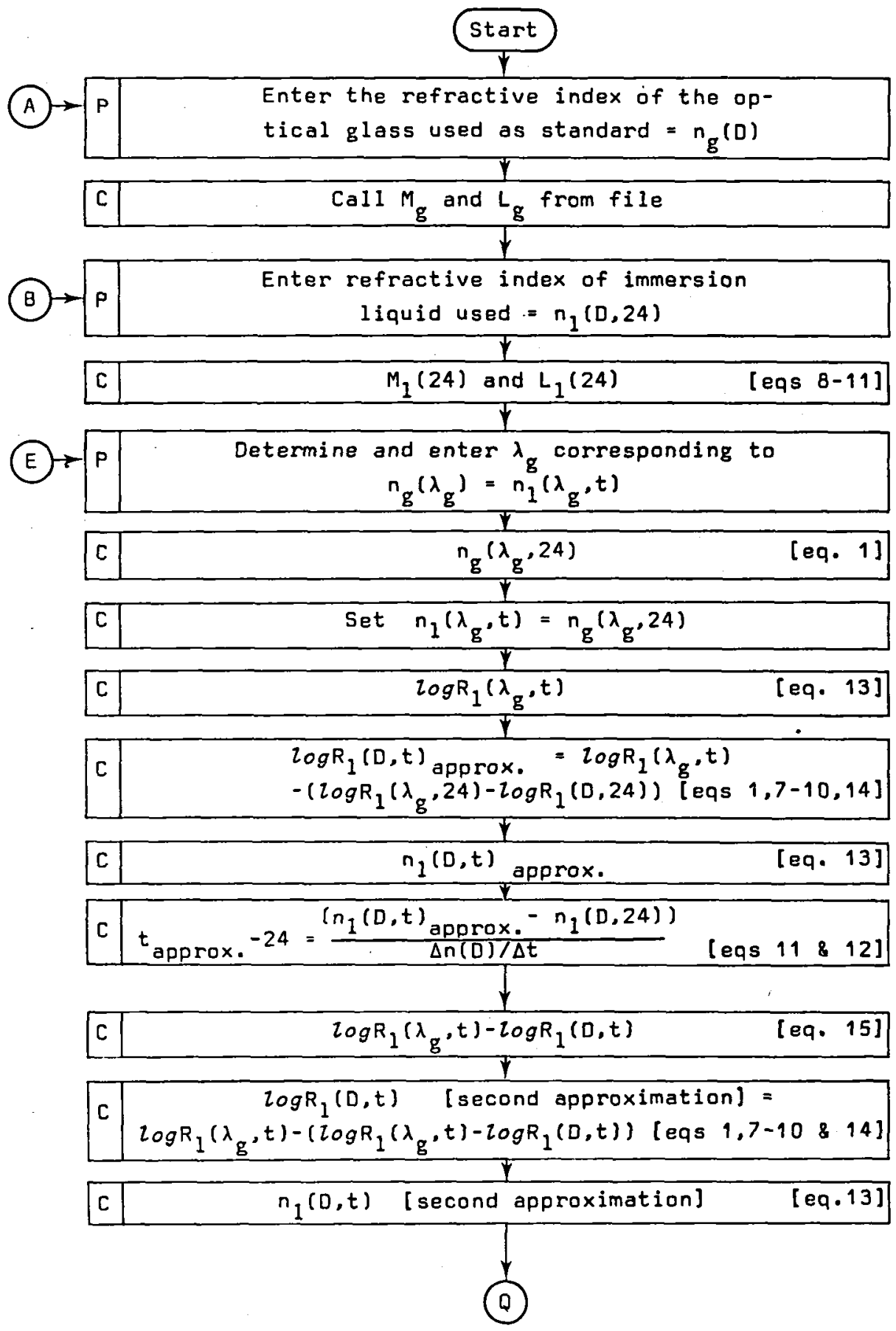




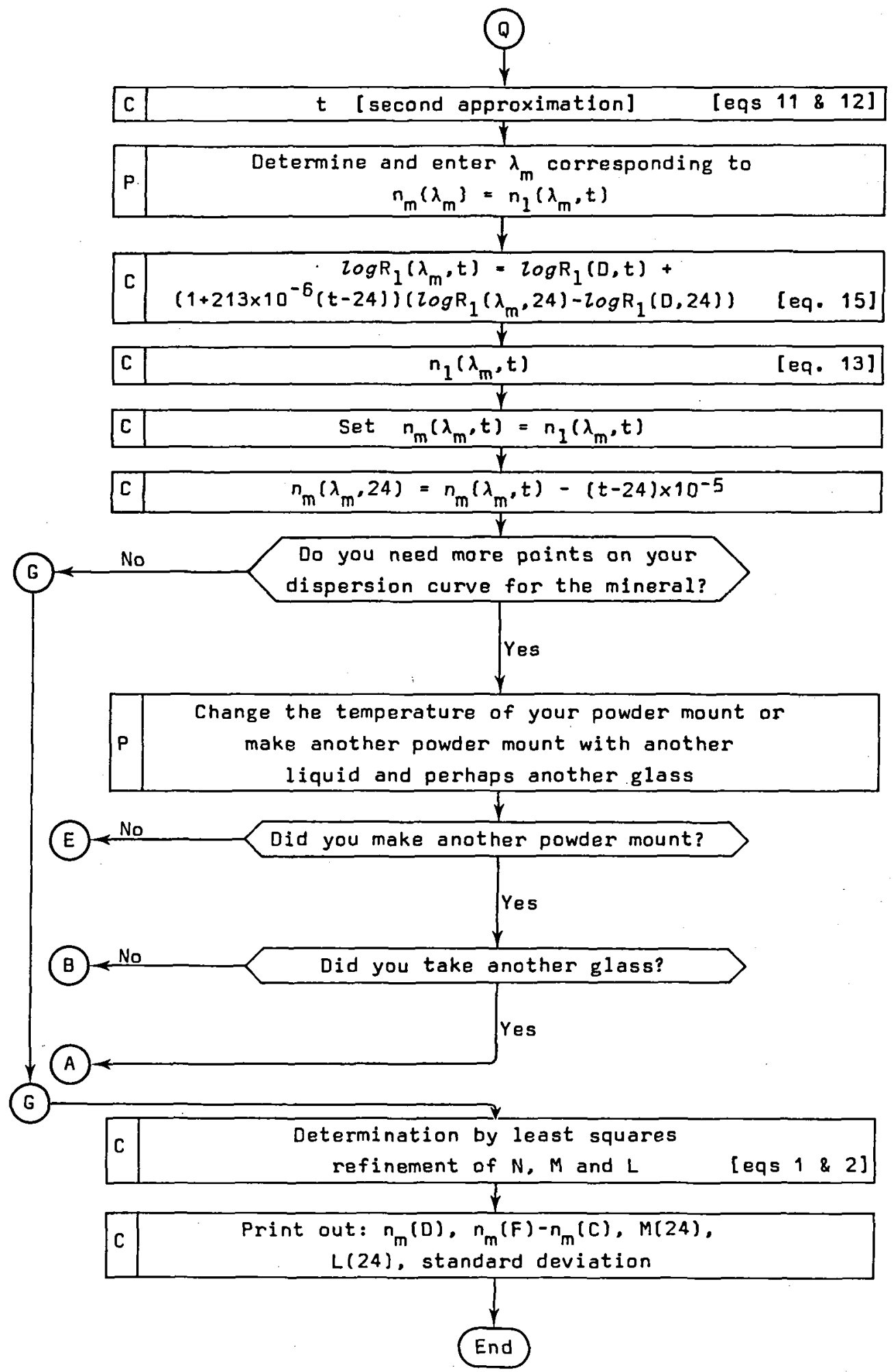




$$
r(\lambda)=\frac{1}{d} \times R(\lambda, t), \text { where } R(\lambda, t)=\frac{n^{2}(\lambda, t)-1}{n^{2}(\lambda, t)+2}
$$

If the specific refraction is independent of temperature we should be able to write $\log \mathrm{R}(\lambda, \mathrm{t})-\log \mathrm{R}(\mathrm{D}, \mathrm{t})=\log \mathrm{R}(\lambda, 24)-\log \mathrm{R}(\mathrm{D}, 24)$

This means that dispersion curves with $\log (\mathrm{R})$ as ordinate should be displaced parallel when the temperature changes. One dispersion curve and $\frac{\Delta \mathrm{n}(\mathrm{D})}{\Delta \mathrm{t}}$ should therefore be sufficient to calculate the refractive index of one liquid at all temperatures and wavelengths, assuming $\Delta n(D) / \Delta t$ to be independent of the temperature. This is nearly the case, but not fully. The measurements actually give a temperature coefficient slightly different from zero.

$\frac{\frac{\Delta(\log \mathrm{R}(\lambda \mathrm{gt})-\log \mathrm{R}(\mathrm{D}, \mathrm{t}))}{\Delta \mathrm{t}}}{\log \mathrm{R}(\lambda, 24)-\log \mathrm{R}(\mathrm{D}, 24)}=(213 \pm 27) 10^{-6}$ degree $^{-1}$

Within the limits of accuracy, this is independent of the spectral line and of the liquid used. The $\log$ R-dispersion is therefore not constant, but increases by $0.0213 \%$ per degree centigrade. A change of $+30^{\circ}$ will change the $\log \mathrm{R}$-dispersion by $0.6 \%$ corresponding to maximum errors of $3 \times 10^{-4}$ in the blue part of the spectrum if the temperature coefficient is neglected. This is insignificant for most measurements but is easily corrected for by use of eq. 15 .

When we combine the dispersion formula (eq. 1), with the interpolated temperature gradients (eqs. 11 or 12) and with the correction for changes in dispersion with temperature (eqs. 13 and 15), we can calculate the refractive index for any liquid in the two series at any wavelength and temperature. The standard deviation has now increased to ca. $70 \times 10^{-6}$.

The greatest sources of error in refractive index measurements by the immersion method are variations in temperature and changes in the composition of liquid mixtures. These errors, however, can be largely eliminated by use of optical glass powder as internal standard (Micheelsen 1957).

\section{Optical glass}

The dispersion values for optical glasses can be read in the catalogues of the optical glass works to $\pm 20 \times 10^{-6}$. Least squares refinement show that all glasses except the DEDF glasses (Double Extra Dense Flint) can be described by $\lambda_{0}=135$ and $p=1.08$ with a standard deviation of $9 \times 10^{-6}$. The DEDF-glass can be described by $\lambda_{0}=170 \mathrm{~nm}$ and $\mathrm{p}=1.27$ with a standard deviation of $13 \times 10^{-6}$. The glasses show no useful relation between $M$ and L. Examples given in table 4 show that flint glasses and crown glasses at the same $n(D)$ value have approximately the same $\mathrm{M}$-value and that the difference in dispersion is connected with the much larger $L$-value of the flint glass.

Table 4. Dispersion coefficients for some optical glasses used as standards for refractive index measurements.

\begin{tabular}{|c|c|c|c|c|c|c|}
\hline \multicolumn{3}{|c|}{$\begin{array}{l}\lambda_{0}=135 \mathrm{~nm}, \mathrm{p}=1.08 \\
\text { wavelength in } \mathrm{nm}\end{array}$} & $\mathrm{n}$ (D) & $\begin{array}{c}n(F)-n(C) \\
\times 10^{-3}\end{array}$ & $\mathbf{M}$ & L \\
\hline Chance & Glass & $\mathrm{HC}$ & 1.52391 & 8.99 & 12.82 & 579.3 \\
\hline$»$ & $»$ & LBC & 1.55021 & 8.72 & 13.23 & 289.2 \\
\hline$"$ & $"$ & $M B C$ & 1.57210 & 9.92 & 14.09 & 659.7 \\
\hline$"$ & $»$ & DBC & 1.60129 & 10.01 & 14.61 & 527.3 \\
\hline$"$ & $»$ & SBC & 1.65069 & 11.11 & 16.04 & 648.5 \\
\hline$"$ & $"$ & SBC & 1.69087 & 12.61 & 17.85 & 855.9 \\
\hline$"$ & $»$ & SBC & 1.71986 & 14.32 & 19.26 & 1317.2 \\
\hline " & $»$ & ELF & 1.54877 & 12.07 & 14.60 & 1661.2 \\
\hline$\eta$ & $"$ & BLF & 1.57415 & 11.04 & 14,47 & 1144.5 \\
\hline$\gg$ & $»$ & DF & 1.62609 & 17.59 & 18.00 & 3537.7 \\
\hline$»$ & $"$ & BF & 1.66052 & 18.31 & 18.53 & 3750.2 \\
\hline 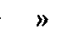 & $"$ & SBF & 1.74383 & 16.64 & 20.80 & 2065.8 \\
\hline
\end{tabular}

The figures in this table are calculated from data given by Chance-Pilkington (1961).

\section{Double variation method}

The double variation method for measuring refractive indices of powders was introduced by Emmons (1943). The method involves variation of the wavelength of the light and of the temperature of the powder mount. The method is rapid and, when optical glass is used as internal standard, accurate (Micheelsen 1957). The double variation method is complicated, however, by the use of dispersion curves for many liquids at many temperatures. Another draw-back is that the shapes of the dispersion curves have not been known with sufficient accuracy, as the Hartmann nets commonly used do not give straight dispersion curves.

The dispersion formulas given in this paper remedy the problem with the Hartmann net. Furthermore, when determining the points on the dispersion curve of the mineral, the interpolation 
formulas, eqs 7-10 and the temperature correction formulas eqs 11-15 make the multitude of dispersion curves unnecessary. Finally, the graphical determination of $n(D)$ and $n(F)-n(C)$ can be replaced by an automatic data treatment using a least squares refinement with eqs 2 and 3.

The way of calculation will depend on the experimental conditions: 1) Is the temperature read on a thermometer or determined from the refractive index of a glass standard? 2) Is the liquid stable or, if it is unstable, is the change controlled by a glass standard or not?

The flow programme given in table 3 describes the double variation method using optical glass as internal standard. The temperature of the specimen is controlled by means of the refractive index of the liquid. In principle the immersion liquid is assumed to be chemically stable but in fact the high index series is not stable. The change in dispersion corresponding to a decrease in $n(D)$ of these liquids is, however, not much different from the effect of an increase in temperature. Minor changes in the composition of the liquid are therefore registered as an increase in temperature and will not give significant errors. However, the marginal parts of the powder mount should be avoided (Micheelsen 1957).

A second assumption is that the $\Delta n(D) / \Delta t$ of the mineral is equal to that of the optical glass, whereby they will cancel each other in the final result. According to Offret (1890) $\Delta n(D) / \Delta t$ ranges from 0 to $-16 \times 10^{-6}$ degree $^{-1}$ for a number of minerals.

According to Chance-Pilkington the coefficient of linear thermal expansion of the optical glasses used here range from 6 to $9 \times 10^{-6}$ degree $^{-1}$. The coefficient of linear expansion can be converted approximately to the temperature coefficient of the refractive index by use of eq. 13, giving -13 to $-24 \times 10^{-6}$ degree $^{-1}$. Temperature variation with optical glass as internal standard is therefore likely to give errors in $n(D)$ of $+(1 \pm 1) \times 10^{-4}$ for each $10^{\circ}$ rise from room temperature. This average correction is used in the programme.

A third assumption is that the change in dispersion with temperature is neglible for the mineral as well as for the glass. This error can also be estimated by use of eq. 13. It will not exceed $1 \times 10^{-5}$ and is therefore neglected.
Acknowledgements. The author is deeply indepted to professor, dr. phil Arne Noe-Nygaard who encouraged and supported the lengthy work of determining the dispersion curves of the immersion liquids used as a basic tool for mineral investigation. Mag. scient. John Rose-Hansen is acknowledged for his persistent help during the long series of goniometric readings. Lektor T. C. R. Pulvertaft is thanked for improving the English manuscript. The project was supported by the Dansih Natural Science Research Counsil (j.nr. 511-6658).

\section{Dansk sammendrag}

En ny formel for optiske dispersionskurver gør det muligt at beregne lysbrydningsforholdet som funktion af bølgelængden med bedre nøjagtighed end $10^{-5}$. Tabeller giver de optiske konstanter for nogle mineraler, for vore almindelige lysbrydningsvæsker og for en del optiske glasser. Endvidere fremlægges hjælpeformler og et flow program, som ger det muligt at anvende databehandling ved brug af kombineret bølgelængde- og temperaturvariation til lysbrydningsmảling pá mineraler.

\section{References}

Cauchy, L. (1830): Sur la dispersion de la lumiére. Bull. Sci. math. 14: 9.

Chance-Pilkington (1961): Optical Glass, Catalogue. St. Asaph, Flintshire, Great Britain.

Emmons, R. C. (1943): The Universal Stage. Geol. Soc. Amer. Mem. 8.

Hartmann, J. (1898): Uber eine einfache interpolationsformel für das prismatische spectrum. Publicationen Astrophysikalischen Observatoriums zu Potsdam (42). 12 Anhang.

Lorenz, L. V. (1863-64): Ueber die Theorie des Lichtes. Poggendorff Ann. 118: 111 \& ibid. 121: 579-593.

Lorentz, H.-A. (1880): Ueber die Beziehung zwichen der Fortplanzungs-Geschwindigkeit des Lichtes und der Korperdichte. Wiedemanns Ann. 9: 641.

Micheelsen, H. (1957): An immersion method for exact determinations of refractive indices. Meddr Dansk geol. Foren. 13: 177-191.

Mülheims, A. (1888): Ueber eine neue Art der Axenwinkelmessung und über die Bestimmung von Brechungsexponenten nach der Methode der Totalreflexion. Zeitschr. Kryst. Min. 14: 202-236.

Offret, A. (1890): De la variation, sous l'influence de la chaleur, des indices de réfraction de quelques espèces minérales, dans l'étendue du spectre visible. Bull. Soc. française Min. 13: 405-617.

Sosman, R. B. (1927): Properties of Silica. New York: Chemical Catalog Company. 